\title{
Characterization of paralic paleoenvironments using benthic foraminifera from early Cretaceous deposits (Scotian Shelf)
}

\author{
Flavia Fiorini ${ }^{1}$; David B. Scott ${ }^{2} \&$ Grant D. Wach ${ }^{2}$ \\ ${ }^{1}$ Smithsonian Tropical Research Institute, CTPA, Ancon, Panama \\ FioriniF@si.edu \\ ${ }^{2}$ Department of Earth Sciences, Dalhousie University, Halifax, \\ Nova Scotia B3H 4J1, Canada
}

The foraminifera from an early Cretaceous cored interval of Cohasset A-52 well (located on the Scotian Shelf- North Atlantic), were used to interpret the depositional environments of these rocks.

Paleoenvironmental interpretation was based on the analysis on samples from four cored intervals of the well corresponding to $25 \mathrm{~m}$ of interbedded gray-black shale, mudstone and sandstone belonging to the Cree Member of the Logan Canyon Formation (Aptian-Albian).

The foraminiferal association recorded in the samples is comprised mainly of agglutinated specimens of Trochammina, Haplophragmoides, Ammobaculites and Verneulinoides and is comparable at the generic level with the microfauna that live in present marshes. The species are also almost identical to Cretaceous faunas recovered in the Rocky Mountain sections of Alberta and Utah.

A scattered occurrence of calcareous benthic foraminifera and thecamoebians is also recorded. The comparison of this microfauna with modern and fossil foraminiferal associations from paralic environment suggests that the studied sediments were deposited in a marsh-estuarine environment.

A $10 \mathrm{~cm}$ thick sandstone containing rare fragments and shells of calcareous marine foraminifera has been recorded in one of the studied cores. The sandstone is deposited on a mudstone and overlain by another one. Marsh foraminifera (mainly belonging to the genus Trochammina) are recorded either in the mudstone deposited before and after. On the basis of paleontological and sedimentological investigation the sandstone is interpreted as a hurricane event deposit preserved within marsh sediments, perhaps the earliest hurricane trace ever found. This hurricane trace is comparable with modern ones. 